\title{
EFL learning among motivated and demotivated Iranian seminary students
}

\author{
Aprendizaje del inglés como lengua extranjera entre los \\ estudiantes iraníes del seminario motivados y desmotivados
}

\author{
Ahmad MolaVI \\ Islamic Azad University, Khorasgan Branch \\ (Isfahan, Iran) \\ Reza BIRIA \\ Islamic Azad University, Khorasgan Branch \\ (Isfahan, Iran)
}

\begin{abstract}
Demotivation is a relatively new issue in the field of second/foreign Language (L2) learning motivation. Recognizing and removing barriers can have a marked effect on motivation and attention to learning in general and ESL/EFL learning in particular. In the present study, an attempt has been made to distinguish the significant difference between EFL achievement of the motivated and demotivated Iranian seminary students. Fifty Iranian EFL seminary students were investigated using three validated questionnaires and tests. In the first stage 50 participants from among Iranian Islamic seminary students in Isfahan, Iran were selected through simple random sampling by the application of Oxford Placement Test (OPT, Allan, 1992) in order to select intermediate homogenous students. In the next stage, the modified version of Gardner's Attitude/Motivation Test Battery (AMTB) questionnaire was applied to understand which students were motivated and which ones were not. Finally a general English proficiency test, namely, Interchange Objective Placement Test (IOPT) was administered to check the students' English proficiency. It was found that demotivation definitely affects EFL learning. The results of the t-test, which was run between the means of the IOPT (English proficiency), for the two groups also show that those students whose AMTB score was higher also scored higher in the proficiency test. Accordingly, devising skills to motivate students to the greatest extent should be seen as central to teaching effectiveness and English language teachers and policy makers should try to find out different strategies in this regard.
\end{abstract}

Key Words: motivation; demotivation; EFL; seminary students; Iran.

\section{Resumen}

La desmotivación es un tema relativamente nuevo en el campo de la motivación para el aprendizaje de una segunda lengua (L2) o una lengua extranjera. La identificación y eliminación de barreras puede tener un efecto marcado sobre la motivación y la atención al aprendizaje en general y al aprendizaje de lenguas extranjeras en particular. En el presente estudio se ha intentado distinguir la diferencia significativa entre el rendimiento en EFL de los estudiantes seminaristas iraníes motivados y los desmotivados. Cincuenta estudiantes seminaristas iraníes de EFL fueron investigados utilizando tres cuestionarios validados y tests. En la primera etapa 50 participantes de entre estudiantes iraníes del seminario islámico en Isfahán, Irán, fueron 
seleccionados mediante un muestreo aleatorio simple por la aplicación del Oxford Placement Test (OPT, Allan, 1992) con el fin de seleccionar a estudiantes intermedios homogéneos. En la siguiente etapa, se aplicó una versión modificada del cuestionario Attitude/Motivation Test Battery (AMTB) de Gardner para entender cuáles de los estudiantes estaban motivados y cuáles no. Por último, se administró un test de proficiencia de inglés general, específicamente el Interchange Objective Placement Test (IOPT), para verificar la competencia en inglés de los estudiantes. Se encontró que la desmotivación definitivamente afecta el aprendizaje del inglés como lengua extranjera. Los resultados del t-test, que se ejecutó entre los medios de la IOPT (en Inglés), para los dos grupos también muestran que aquellos alumnos cuya puntuación en el AMTB fue mayor, también puntuaron más alto en la prueba de proficiencia. En consecuencia, la elaboración de habilidades para motivar a los estudiantes al máximo debe considerarse como un elemento central para la efectividad en la enseñanza, y los profesores de inglés y los responsables de las políticas deben tratar de encontrar diferentes estrategias en este sentido.

Palabras Claves: motivación; desmotivación; inglés como lengua extranjera; estudiantes del seminario; Irán.

\section{INTRODUCTION}

Dörnyei (2005) notes that motivation plays a critical role in academic learning in general and specifically for the "sustained process of mastering an L2". The Longman Dictionary of Contemporary English (2007) defines motivation as: "Eagerness and willingness to do something without needing to be told or force to do it". The term motivation is used constantly in everyday and professional contexts, but defining motivation precisely is a demanding task due to its complex and multifaceted nature (Dörnyei, 2001). Motivation with respect to language learning poses even a more challenging dilemma because compared to other school subjects, learning a language presents a unique situation due to its role and nature (Dörnyei, 1994). Thus far, most motivation research has focused on well-adjusted students who are successful in school; however; successful students differ from their less-successful peers in many ways. Dornyei (2005) defines demotivation as "specific external forces that reduce or diminish the motivational basis of a behavioral intention or an ongoing action" (p. 143). These negative external factors include items such as the class environment, teaching situations, methods, and teacher's behavior.

It is worth explaining that seminary students are religious students studying theology in theological schools. Because of personal interest or being interested in learning English to propagate Islam, the students who participated in this project were studying English in the Islamic Propagation Office, which is the center for extra school studies of seminary students. Not all of these students seemed sufficiently interested in pursuing L2 learning; therefore, an effort has students. Latin American Journal of Content and Language Integrated Learning, 6(1), 55-66. 
been made in this study to identify the demotivating factors negatively influencing their EFL learning.

\section{Literature review}

Over the last twenty years, research on motivation for foreign language learning has evolved considerably from focusing on describing what composes student motivation to a detailed and elaborated list of suggestions that help teachers initiate and further promote student motivation. However, because of the novelty of the term demotivation, not much research has been conducted on the subject. In other words, despite the probable importance of demotivation for learning in general, and for L2 and FL learning in particular, to date few studies have focused on student demotivation. This section deals with the previous studies on motivation and demotivation.

Falouta, Elwoodband, and Hood (2009) conducted a study on 900 university EFL learners to investigate demotivating factors in learning EFL in Japan, and the relationship between past demotivating experiences and present proficiencies. In their study, demotivating factors were grouped into three categories: external conditions of the learning environment, internal conditions of the learner, and reactive behaviors to demotivating experiences. Internal and reactive factors were shown to correlate with long-term EFL learning outcomes.

Trang and Baldauf (2007) investigated demotivation in Vietnamese students at an economics university with three main foci: (1) the reasons (that is, the demotives) underlying demotivation, (2) the degree of influence of different motives, and (3) student experiences in overcoming demotivation.

Keblawi (2006) studied demotivation of Arab learners of English. Participants in this study were 294 Arab learners of English in Israel in years 9 and 10 (aged 15 and 16). The demotivating factors that students referred to, and that were related to teachers, were classified into two main groups: teachers' style (that is, the way they taught and presented the material to students), and personality traits (that is, the way they behaved with students). Furthermore, various other factors such as textbooks and evaluation system were also identified by learners as demotivating.

Lantolf and Genung (2002) conducted a case study of a graduate student learning Chinese as a foreign language in a summer intensive course. They found 
that the learner became demotivated because of the teacher's authoritative use of power.

Dorniyei (2001) conducted a study of 50 secondary school pupils in Budapest who were studying either English or German as their second language. The data were collected through structured interviews. He identified the teacher, lack of self-confidence, negative attitudes toward the L2, the compulsory nature of L2 study, interference of other languages, negative attitudes towards the L2 community, attitudes of group members, the course book, and inadequate school facilities as nine demotivating factors.

Oxford (1998) took into account the time factor. She recognized that some of demotivating factors can include the teacher, the textbook, negative classroom activities, defective equipment, and inappropriate tasks.

Takako (2005) studied the influence of teachers on learner motivation in an L2 classroom. The purpose of this paper was to survey existing research on teacher influence on learner motivation in L2 language classrooms. The findings showed that teachers have considerable influence on learner motivation and that several general implications exist pertinent to classroom practice.

Kiss and Nikolov (2005) explored the relationship between the aptitude scores of 419 Hungarian primary-school children on English proficiency tests and a designated measure of their motivation. The results showed that the variable of language aptitude was responsible for over 20\% of the variation in English language performance, while motivation was also significant as it explained about $8 \%$ of the variation.

Mora Vázquez, Trejo Guzmán, and Roux Rodríguez (2010) conducted a small scale investigation into Mexican university students' language learning motivation. The participating students in this study identified teacher-specific motivational components and group-specific motivational components as the two most influential factors from their learning context in determining their L2 learning motivation levels.

A review of the existing literature on demotivation suggests a need for further research in the field. As can be seen, although some of the previously mentioned studies explored the demotivating factors and tried to distinguish them in different contexts, no study has previously been done regarding demotivation in Iranian contexts. Along with these other studies, the current study attempts to investigate demotivation amongst Iranian seminary students 
and identify the most influential factors on demotivation regarding EFL learning in Iranian seminary students. It is worth mentioning here that the staff involved in the teaching of EFL to Iranian seminary students have proposed continuous and practical elaboration to seminary school professors and Islamic Propagation Office about the necessity of learning English as a foreign language, providing sufficient encouragement and paying enough attention to the selection and screening processes of students as means to overcome students' demotivation and the results of implementing such strategies in this particular context.

\section{Statement of the Problem}

A number of studies, including Gardner (1985), Domyel (2001), Csizer and Kormos (2008), and Mora Vázquez, Trejo Guzmán, and Roux Rodríguez (2010), have been conducted to determine whether the student motivation has any significant impact on their learning. However, despite these studies on the effects of motivation on learning, the significance of motivation's negative side-namely, demotivation-has been underestimated. More studies are required to further illustrate the causes and consequences of demotivation.

Moreover, review of the existing literature suggests that no study focusing on the identification of L2 learning demotives has been conducted in Iranian Islamic seminary schools-thus, this forms the focus of the present study. This study also aimed to find out whether there is a meaningful relationship between the amount of motivation and the performance of Iranian Seminary EFL learners in IOPT tests.

\section{Research Question}

The following questions were addressed in the current study:

1. How meaningful is the difference between EFL achievement of the motivated and demotivated Iranian Islamic seminary students?

2. To what extend does demotivation affect EFL learning of Iranian Islamic seminary students?

\section{Research Hypotheses}

Based on studies done on the intended research group, consultation with the experts in the field, and researchers' long experience in teaching EFL to Iranian 
seminary students, the following hypothesis was formulated: There is no significant difference between EFL achievement of the motivated and demotivated seminary students.

\section{METHODOLOGY}

\section{Participants}

The study was done with 50 intermediate Iranian EFL male seminary students aged between 20 and 30 who came from different Islamic seminary schools located in the Province of Isfahan, selected through simple random sampling from among Iranian Islamic seminary students who were studying English in Islamic Propagation Office.

\section{Instrumentation}

The first instrument which was used in this study was a standard English language placement test, the Oxford Placement Test (OPT, Allan, 1992), in order to select intermediate students. Its reliability and validity have already been confirmed by the test designer (Allan, 1992). The next instrument used to distinguish between motivated and demotivated students under study was Gardner's Attitude/Motivation Test Battery (AMTB) questionnaire (Gardner, 2004). The original questionnaire included 116 items (showing how some students feel about EFL learning), out of which 70 items were chosen and the rest were deleted (because they were too lengthy or too culture-bound). The remaining items were translated into Persian in order to prevent any L2 misunderstanding; then they were checked by two Persian language teachers and a translation instructor in order to make sure that the items retained their essential meaning and that the translated version was easily understood. To ascertain the reliability of the items, a pilot study was conducted with 30 Islamic seminary students who were not supposed to take part in the main experiment. In order to obtain a cut-off point to distinguish the motivated students from the demotivated ones, the mean score of the pilot study was computed and the score of 203 was obtained and was set as the cut-off point.

In order to identify the English knowledge of the participants, a general English proficiency test (Interchange Placement Test, Interchange Placement and Evaluation Package, 3rd edition, 2005) was applied. This test was composed of 3 
sections: a listening section (20 questions), a reading section (20 questions), and a language use section (30 questions). All items were multiple-choice questions.

\section{Procedures}

In the first stage, 50 intermediate homogenous participants were selected through simple random sampling from among Iranian Islamic seminary EFL students in Isfahan, Iran by the application of Oxford Placement Test (OPT, Allan, 1992). In the next stage, the modified version of Gardner's Attitude/Motivation Test Battery (AMTB) questionnaire was applied to understand which students were motivated and which ones were not. Finally the Interchange Objective Placement Test (IOPT) was administered to check the students' English proficiency. This test took 50 minutes to complete: 15 minutes for listening, 20 minutes for reading, and 15 minutes for language use.

\section{RESULTS}

\section{Data analysis}

The data gathered through the questionnaires were tabulated for ease of application. To accept or reject the stated hypothesis, the collected data were analyzed by independent sample $t$-tests to find the difference in the performances of the students in the two groups. All the statistical procedures were conducted by SPSS software version 16.

\section{Results}

The current study investigated the impact of demotivation on EFL learning of Iranian Seminary students. This section comprised two stages; first, the students who were demotivated were to be distinguished from those who were not. To this end, the AMTB was run (which showed teaching materials and books used to teach English developed by the people from the west, lack of selfconfidence, considering English class to be boring, no correspondence between Arabic, being the language of theology studies in Iranian seminary schools and English, , unpleasant English teachers, considering Learning English as a waste of time because most of seminary students expect to be sent to other countries for the purpose of propagation, and since this is not possible for all the students, it leads to the lack of motivation, little interest in English class because English is 
not used in students' daily life and getting anxious when answering a question in English class and feeling uncomfortable speaking English anywhere outside the classroom to be the most important demotivating factors in EFL learning). Then the students were given the IOPT to see if there was a significant difference between the performances of the students in the two groups, namely, the group with high scores in the AMTB $(n=28)$ and those with low scores in the AMTB $(n=$ 22). Table 1 and Table 2 report the scores of the participants in AMTB and IOPT; Table 3 presents the descriptive statistics for the IOPT scores.

Table 1. AMTB and IOPT scores of the participants in the high group

\begin{tabular}{|c|c|c|}
\hline Student No. & AMTB score & IOPT score \\
\hline 1 & 243 & 42 \\
\hline 2 & 206 & 34 \\
\hline 3 & 243 & 30 \\
\hline 4 & 225 & 30 \\
\hline 5 & 224 & 34 \\
\hline 6 & 211 & 44 \\
\hline 7 & 222 & 24 \\
\hline 8 & 229 & 38 \\
\hline 9 & 219 & 42 \\
\hline 10 & 227 & 42 \\
\hline 11 & 222 & 36 \\
\hline 12 & 214 & 40 \\
\hline 13 & 209 & 48 \\
\hline 14 & 219 & 48 \\
\hline 15 & 213 & 48 \\
\hline 16 & 207 & 50 \\
\hline 17 & 214 & 48 \\
\hline 18 & 211 & 34 \\
\hline 19 & 213 & 34 \\
\hline 20 & 226 & 34 \\
\hline 21 & 229 & 38 \\
\hline 22 & 233 & 42 \\
\hline 23 & 235 & 48 \\
\hline 24 & 206 & 48 \\
\hline 25 & 214 & 42 \\
\hline 26 & 217 & 50 \\
\hline 27 & 219 & 53 \\
\hline 28 & 209 & 49 \\
\hline
\end{tabular}


Table 2. AMTB and IOPT scores of the participants in the low group

\begin{tabular}{|c|c|c|}
\hline Student No. & AMTB score & IOPT score \\
\hline 1 & 202 & 70 \\
\hline 2 & 168 & 80 \\
\hline 3 & 184 & 50 \\
\hline 4 & 187 & 73 \\
\hline 5 & 161 & 83 \\
\hline 6 & 168 & 82 \\
\hline 7 & 164 & 58 \\
\hline 8 & 152 & 51 \\
\hline 9 & 197 & 76 \\
\hline 10 & 198 & 49 \\
\hline 11 & 201 & 72 \\
\hline 12 & 181 & 75 \\
\hline 13 & 192 & 59 \\
\hline 14 & 159 & 48 \\
\hline 15 & 140 & 51 \\
\hline 16 & 132 & 82 \\
\hline 17 & 124 & 70 \\
\hline 18 & 110 & 72 \\
\hline 19 & 151 & 40 \\
\hline 20 & 183 & 61 \\
\hline 21 & 194 & 50 \\
\hline 22 & 173 & 48 \\
\hline
\end{tabular}

Table 3. Descriptive statistics for the IOPT

\begin{tabular}{lllll}
\hline Group & $\mathrm{N}$ & Mean & SD & SEM \\
\hline High & 28 & 41.07 & 7.448 & 1.408 \\
Low & 22 & 63.64 & 13.665 & 2.913 \\
\hline
\end{tabular}

Table 3 clearly indicates that the means of the two groups are different. In order to find out whether or not this difference is statistically significant, a $t$-test was employed. Table 4 shows the results of this $t$-test. 
Table 4. Results of the t-test on the IOPT means

\begin{tabular}{llll}
\hline t-observed & df & $p$ & Mean Difference \\
\hline-7.454 & 48 & 0.000 & -22.56494 \\
\hline
\end{tabular}

Table 4 clearly shows that the amount of t-observed (-7.454) is statistically significant at the probability level of $\mathrm{p}=0.000$. In other words, it can be claimed that the highly demotivated participants did more poorly on the proficiency test than less demotivated participants. Therefore, the null hypothesis of the study which stated that there is no significant difference between EFL achievement of the motivated and demotivated seminary students can safely be rejected. In other words, it can be said that motivation and demotivation are determining factors in EFL proficiency achievement.

\section{DISCUSSION}

The results of the present study are in line with the study conducted by Joseph Falout, Elwood and Hood (2009) which found that demotivating factors were grouped into three categories: external conditions of the learning environment, internal conditions of the learner, and reactive behaviors to demotivating experiences. The demotivating factors in EFL learning for Iranian seminary students mentioned above seem to fall in the same categories grouped by Falout et al. (2009).

The point which is fruitful to mention is that unlike other EFL learners which reach an acceptable amount of motivation to continue learning English, seminary students' motivation usually decreases at higher levels for different reasons some of which were discussed in results section, so even intermediate EFL learners prove to be demotivated as it was the case for the demotivated seminary students in the current research..

\section{REFERENCES}

Allan, D. (1992). Oxford Placement Test 2. Oxford, England: Oxford University Press.

Dörnyei, Z. (1994). Motivation and motivating in the foreign language classroom. Modern Language fournal, 78(3), 273-284.

Dörnyei, Z. (2001). Teaching and researching motivation. Harlow, England: Longman. 
Dörnyei, Z. (2005). Teaching and researching motivation. Beijing: Foreign Language Teaching and Research Press.

Dörnyei, Z. (2005). The psychology of the language learner: Individual differences in second language acquisition. London: Lawrence Erlbaum Associates.

Falout, J., Elwood, J. \& Hood, M. (2009). Demotivation: Affective states and learning outcomes. System, 37(3), 403-417.

Gardner, R. C. (2004) Attitude/Motivation Test Battery: International AMTB Research Project. London, Canada: University of Western Ontario. Retrieved from http://publish.uwo.ca/ gardner/docs/englishamtb.pdf

Keblawi, F. (2006). Demotivation among Arab learners of English as a Foreign Language. In M. Singhal \& J. Liontas (eds.), Proceedings of the Second International Online Conference on Second and Foreign Language Teaching and Research-September 16-18, 2005 - Initiative, Innovation, and Inspiration (pp. 49-78). Irvine, CA: The Reading Matrix Inc. Available: http://www.readingmatrix.com/conference/pp/proceedings2005/keblawi.pdf

Kiss, C. \& Nikolov, M. (2005). Developing, Piloting, and Validating an Instrument to Measure Young Learners' Aptitude. Language Learning, 55 (1), 99-150. Retrieved November 29, 2005, from Blackwell Synergy database. Available: http://www.x.amega.hu/doc/letters/longman/all/kissnikolov.pdf

Lantolf, J. P. \& Genung, P. B. (2002). "I'd rather switch than fight": An activitytheoretic study of power, success, and failure in a foreign language classroom. In C. Kramsch (Ed.), Language acquisition and language socialization: Ecological perspectives (pp. 175-196). London, England: Continuum.

Mora Vázquez, A., Trejo Guzmán , N. P., Roux Rodríguez, R. (2010). A small scale investigation into Mexican university students' language learning motivation. Actualidades Investigativas en Educación, 10(1), pp. 1-15. Retrieved from http://revista.inie.ucr.ac.cr/articulos/12010/archivos/scale.pdf

Motivation. (2007). In Longman Dictionary of Contemporary English ( $\left.1^{\text {st }} \mathrm{rev} . \mathrm{ed}.\right)$. Harlow, England: Pearson Education.

Oxford, R. L. (1998). The unravelling tapestry: Teacher and course characteristics associated with demotivation in the language classroom. Demotivation in foreign language learning. Unpublished paper presented at the TESOL '98 Congress, Seattle, WA. 
Reeve, J. (1996). Motivating others: Nurturing inner motivational resources. Boston, MA: Allyn and Bacon.

Takako, T. (2005) Teacher influence on learner motivation. Osaka fogakuin College Kiyo, 35, 49-58. Retrieved from http://www.wilmina.ac.jp/ ojc/kiyo 2005/kiyo $35 \mathrm{PDF} / 2005$ 06.pdf

Trang, T. T. T. Baldauf Jr., R. B. (2007). Demotivation: Understanding resistance to English language learning - The case of Vietnamese students. The Journal of Asia TEFL, 4 (1), 79-105. Retrieved from http://espace.library.uq.edu.au/eserv.php?pid=UQ:23743\&dsID=JnlAsiaTEF L2007 $4 \quad 1$ 79-105Fnl.pdf

Ushioda, E. (1998). Effective motivational thinking: A cognitive theoretical approach to the study of language learning motivation. In A. Alcon \& V. Codina (Eds.), Current issues in English language methodology (pp. 77-89). Castello de la Plana, Spain: Publicacions de la Universitat Jaume I.

\section{BIODATA}

Ahmad Molavı is a Ph. D. student of TEFL at the Islamic Azad University, Khorasgan Branch (Isfahan, Iran). He is currently teaching in Azad Universities and the Islamic Propagation Office in Isfahan, Iran. His research interests include teaching methodology and second language acquisition (SLA), as well as psycholinguistics and sociolinguistics.

Reza BIRIA is a faculty member (assistant professor) in the English Language Teaching Department, Islamic Azad University, Khorasgan Branch (Isfahan, Iran). He holds a Ph. D. in applied linguistics. Dr. Biria's interests are language testing, research methodology, linguistics, and teaching methodology. The author of numerous articles and books, he has also participated in various seminars and conferences and is an experienced professor of English. 